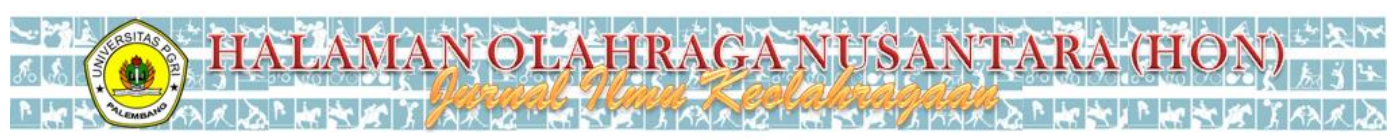

Volume 4 no I

ISSN 2614-2775 (Print)

Tahun 2021

ISSN 2621-8143 (Online)

\title{
PENINGKATAN KETERAMPILAN BERMAIN BOLAVOLI MAHASISWA MELALUI LATIHAN GAYA SELF CHECK
}

\author{
Daryono $^{1}$, Muh. Akmal Almy ${ }^{2}$ \\ Universitas PGRI Palembang, Indonesia \\ mrdary.ion@gmail.com
}

\begin{abstract}
Abstrak
Masalah dalam penelitian ini adalah apakah terdapat pengaruh latihan gaya self check terhadap hasil belajar bola voli mahasiswa semester satu pada pembelajaran bola voli. Penelitian ini bertujuan untuk mengetahui bagaimana kemampuan siswa dalam bermain bolavoli dengan latihan gaya self check. Pada penelitian ini metode yang digunakan adalah metode eksperimen the onegroup pretest-posttest design. Populasi dalam penelitian ini adalah seluruh siswa semester 1 dengan jumlah 150 mahasiswa. Sedangkan sampel penelitian ini berjumlah 30 mahasiswa. Teknik pengambilan sampel dalam penelitian ini menggunakan teknik purposive sampling. Teknik pengumpulan data dengan menggunakan tes keterampilan bermain bolavoli yaitu test servis, test pasing dan test smash. Analisis data dalam penelitian ini menggunakan uji t. Berdasarkan hasil penelitian yang telah dilakukan terdapat peningkatan keterampilan bermain bola voli melalui latihan gaya shelf check, peningkatan keterampilan servis bolavoli didapat rata-rata tes awal 20,15 dan meningkat pada rata-rata tes akhir 30,13, peningkatan ketrampilan pasing 34,32 dan meningkat pada rata-rata tes akhir 45,30, dan terdapat peningkatan keterampilan smash bolavoli didapat rata-rata tes awal 16,80 dan meningkat pada ratarata tes akhir 27,50 .
\end{abstract}

\section{IMPROVEMENT OF STUDENTS PLAYING BOLAVOLI STUDENTS THROUGH SHELF CHECK STYLE TRAINING}

\begin{abstract}
The problem in this study is whether there is an effect of self-check style training on the volleyball learning outcomes of first semester students in volleyball learning. This study aims to determine how the students' ability to play volleyball with self-check style exercises. In this study, the method used was the onegroup pretest-posttest design experimental method. The population in this study were all 1st semester students with a total of 150 students. While the sample of this research is 30 students. The sampling technique in this study was using purposive sampling technique. The data collection technique used a volleyball playing skill test, namely the service test, the passing test and the smash test. Data analysis in this study used the t test. Based on the results of the research that has been done, there is an increase in volleyball playing skills through shelf-check style training, an increase in volleyball service skills obtained by an average of 20.15 in the initial test and an increase in the average of the final test of 30.13, an increase in skills of pasing 34.32 and an increase in the average of the final test 45.30, and there is an increase in volleyball smash skills obtained by an average of 16.80 in the initial test and an increase of an average of 27.50 in the final test.
\end{abstract}

Correspondence author: Daryono, universitas PGRI Palembang, indonesia. E-Mail: mrdary.ion@ gmail.com (c) (i) (2)

Jurnal Halaman Olahraga Nusantara licensed under a Creative Commons Attribution-ShareAlike 4.0 International License. 
Keywords: Volleyball, Self Check Style

\section{PENDAHULUAN}

Sarana Olahraga merupakan aktivitas yang sangat penting untuk mempertahankan kesehatan seseorang.Olahraga juga suatu perilaku aktif yang menggiatkan metabolisme dan mempengaruhi fungsi kelenjar didalam tubuh untuk memproduksi sistem kekebalan tubuh dalam mempertahankan tubuh dari gangguan penyakit serta stres.Oleh kerena itu, peranannya sangat penting serta dianjurkan kepada setiap orang untuk melakukan kegiatan olahraga secara rutin dan terstruktur dengan baik.Selain itu, olahraga juga memiliki peranan dalam pendidikan.

(Adang Suherman 2000) Pendidikan Jasmani, Olahraga dan Kesehatan (Penjasorkes) adalah suatu proses pembelajaran melalui aktivitas jasmani yang didesain untuk meningkatkan kebugaran jasmani, mengembangkan keterampilan motorik, pengetahuan dan perilaku hidup sehat dan aktif, sikap sportif, dan kecerdasan emosi. Juga diartikan sebagai pendidikan yang mengaktualisasikan potensi-potensi aktivitas manusia berupa sikap, tindakan, dan karya yang diberi bentuk, isi dan arah menuju kebulatan pribadi sesuai dengan cita-cita kemanusiaan. (Ma'mun 2001) menyatakan, “nilai-nilai yang terkandung dalam permainan bola voli terdiri dari: 1) Keterampilan gerak, 2) Nilai-nilai sosial, 3) Nilai-nilai kompetitif, 4) Kebugaran fisik, 5) Keterampilan berfikir, 6) Suasana Emosi, 7) Tertib hukum dan aturan”. Sedangkan menurut (Viera 2004) bola voli menjadi pemainan yang menyenangkan karena alasan-alasan sebagai berikut: 1) Olahraga ini dapat beradaptasi terhadap berbagai kondisi yang mukin timbul didalamnya. 2) Olahraga ini dapat dimainkan dan dinikmati oleh segala usia dan tingkat kemampuan. 3) Olahraga ini dapat dimainkan disegalah bentuk permukaan rumput, kayu, pasir, dan berbagai macam permukaan lantai buatan. 4) Olahraga 
ini sangat baik sebagai kegiatan antar jenis kelamin. 5) Olahraga ini menarik bagi penonton pertandingan.

Permainan bola voli semakin berkembang terutama pada tahun-tahun terakhir ini, sejalan dengan perkembangan permainan ini, berkembang pula metode-metode pelatihan dengan kombinasi teknik yang lebih efektif dan efisien. Dengan begitu, banyak negara yang sebelumnya tidak diperhitungkan prestasinya dapat menghasilkan tim yang kompak dan disegani, karena tiap-tiap tim mampu memanfaatkan potensi yang ada secara optimal. Potensi tim meliputi dalam group dan potensi yang dimiliki setiap pemain. (Pangrazi 2004) menyatakan bahwa keterampilan dasar adalah keterampilan yang bermanfaat yang dibutuhkan anakanak sebagai bekal hidup dan bersikap. (Samsudi 2005) dalam bidang pendidikan, penelitian dan pengembangan dapat digunakan untuk mengembangkan model pembelajaran, materi dan bahan pembelajaran, media pembelajaran, model-model kurikulum, manajemen pendidikan dan lainnya.

Permainan bola voli yang sudah memasyarakat banyak digemari bukan hanya dari kalangan bawah saja, tetapi dari seluruh lapisan masyarakat dari perkotaan hingga pelosok desa. Pada umumnya masyarakat sangat antusias dan menggemari untuk memainkannya. Kalau ditinjau dari segi pemasalan berkaitan dengan panji olahraga dengan memasyarakatkan olahraga dan mengolahragakan masyarakat, cabang olahraga bola voli telah berhasil dari segi pemasyarakatan dan pemasalan. Sehingga secara keseluruhan pemasalan bola voli di Indonesia dianggap telah berhasil. Tetapi keberhasilan suatu pemasalan belum dapat 
$\overline{\text { menjamin tercapainya prestasi olahraga setinggi-tingginya (Sukirno dan Waluyo }}$ 2012).

Sebagian besar lapisan masyarakat tahu bagaimana cara bermain bola voli dan pernah memainkan permainan ini dalam rangka pertandingan mulai dari antar kelas sampai pertandingan antar sekolah untuk merebut tiket juara wilayah menuju puncak juara nasional. Kualitas pembelajaran disekolah dan program ekstrakurikuler yang baik, klub-klub yang bagus menjadi sarana yang tepat bagi pembinaan untuk para calon atlet yang berprestasi, sejak dini anak-anak yang dianggap mampu mengikuti berbagai macam pertandingan dari tingkatan yang rendah sampai ketingkatan yang tinggi. Ini akan memberikan pengalaman yang berharga bagi anak.

Dalam permainan bola voli terdapat suatu teknik dasar yang meliputi servis, passing, smash, dan block. "Keterampilan dalam melakukan passing, smash atau spike, servis dan keterampilan dalam melakukan bendungan" (Marta Dinata 2004) Untuk dapat memainkan bolavoli dengan baik, maka dibutuhkan pengusaan keterampilan bermain bolavoli yang baik pula oleh pemainnya. Selain itu, penguasaan materi mata kuliah bolavoli diperlukan metode yang efektif dan efisien, terutama dalam penggunaan metode dalam mengajar. Dapat memiliki keterampilan yanberkualitas maka diperlukan latihan yang berkelanjutan. Menurut (Bompa 2000) menyatakan Latihan adalah "proses dimana seorang pemain dipersiapkan untuk performa tertinggi”. 
(Giriwijoyo, S dan Sidik 2005) mengatakan bahwa olahraga adalah

serangkaian gerak raga yang teratur dan terencana. Salah satu cabang dari olahraga adalah permainan bolavoli, permainan bolavoli adalah salah satu mata kuliah, yang pembahasannya mencakup tentang teknik-teknik dasar dalam bermain bolavoliPermainan bolavoli merupakan salah satu matakuliah yang masuk didalam kurikulum pada program studi pendidikan olahraga FKIP Universitas PGRI Palembang. Berdasarkan wawancara nonformal kepada mahasiswa yang pernah mengikuti matakuliah ini, matakuliah ini sulit dilaksanakan apabila gaya mengajar dosen monoton, sehingga peningkatan kemampuan belajar masih rendah. Penyebab rendahnya keterampilan bermain bolavoli mahasiswa dalam pembelajaran tersebut perlu mendapat perhatian, dicari penyebabnya, dan segera diatasi.

Kenyataan tersebut mendorong peneliti untuk melihat hasil belajar bolavoli yang dimiliki oleh mahasiswa dan secara khusus memberikan latihan gaya selfcheck dalam bentuk eksperimen guna melihat peningkatan hasil belajarmatakuliah bolavoli mahasiswa. Latihan gaya self check diberikan kepada mahasiswa agar dapat membantu mahasiswa mengembangkan kreatifitas mahasiswa dalam selama perkuliahan. Menurut (Mosston 2008) "Gaya selfcheck adalah hubungan guru dengan siswa yang menuntut keputusan ditentukanoleh siswa, yang berarti lebih banyak tanggung jawab yang dituntut".

Adapun Tujuan yang ingin dicapai dari penelitian ini adalah untuk mengetahui peningkatan keterampilan bermain bolavoli mahasiswa melalui latihan gaya self check. 


\section{METODE}

Metode yang digunakan dalam penelitian ini adalah metode eksperimen. (Suharsimi 2006) "populasi adalah keseluruhan subjek penelitian". Populasi dibatasi sebagai sejumlah penduduk atau individu yang paling sedikit mempunyai sifat yang sama. Populasi dalam penelitian ini adalah mahasiswa mata kuliah permainan bola voli prodi pendidikan olahraga Universitas PGRI Palembang yang berjumlah 150 orang. Sampel dalam penelitian ini berjumlah 30 siswa menggunakan teknik proposive sampling. Penelitian ini menggunakan desain the one group pre test-post test design. Dalam melakukan penelitian ini data yang diperlukan diungkapkan dengan mengunakan tes keterampilan bermain bolavoli (Depdiknas 1999) yang terdiri dari Tes Servis, Passing, dan Smash.

Untuk melihat deskripsi data hasil pre test dan post test digunakan teknik statistik yaitu dengan mencari skor dari mean (rata-rata), standar deviasi, range, skor minimum dan skor maksimum. Kemudian, untuk menguji signifikansi perbedaan antara hasil pretest dan posttest keterampilan, maka digunakan rumus uji t (t-test), sesuai dengan pendapat (Thomas. J.R. dkk 2015) yang mengatakan bahwa "efektifitas atau pengaruh dari perlakuan dilihat dari perbedaan antara pretest dan post test dengan menggunakan analisis statistik dengan t-test sample dependent.

\section{HASIL DAN PEMBAHASAN}

Berdasarkan analisis data test awal (pre test) dan test akhir (post test) servis, pasing dan smash diperoleh hasil dalam tabel distribusi frekuensi berikut:

\section{Tabel 1 Distribusi Frekuensi Data Hasil Servis}

\begin{tabular}{lcccccr}
\hline No & Kelas Interval & $\begin{array}{c}\text { Test Awal } \\
\text { Fa }\end{array}$ & \multicolumn{2}{c}{ Kelas Interval } & Test Akhir & \\
& & & & $\mathrm{Fa}$ & $\mathrm{Fr}(\%)$ \\
\hline 1 & $15.00-16.88$ & 3 & 10 & $26.00-28.22$ & 5 & 16,7 \\
\hline
\end{tabular}




\section{OLAHRAGA}

NUSANTARA JURALULHUKCOLDIRAQHA
Jendral A. Yani Street Lorong Gotong Royong 9/10 Ulu Palembang South Sumatera

email jurnal: jurnalhon@univpgri-palembang.ac.id situs web: http://www.univpgri-palembang.ac.id
Accredited

SINTA 3

\begin{tabular}{ccclccc}
\hline 2 & $16.89-18.77$ & 2 & 6,7 & $28.23-30.45$ & 6 & 20 \\
\hline 3 & $18.79-20.67$ & 5 & 16,7 & $30.46-32.68$ & 9 & 30 \\
\hline 4 & $20.68-22.56$ & 7 & 23,3 & $32.69-34.91$ & 4 & 13,3 \\
\hline 5 & $22.57-24.45$ & 9 & 30 & $34.92-37.14$ & 3 & 10 \\
\hline 6 & $24.46-26.34$ & 4 & 13,3 & $37.15-39.37$ & 3 & 10 \\
\hline
\end{tabular}

Tabel 2 Distribusi Frekuensi Data Hasil Passing

\begin{tabular}{lcclccc}
\hline No & Kelas Interval & Test Awal & \multicolumn{2}{c}{ Kelas Interval } & Test Akhir & \\
& & Fa & Fr $(\%)$ & & Fa & Fr $(\%)$ \\
\hline 1 & $22.00-26.44$ & 5 & 16,7 & $37.00-40.25$ & 5 & 16,7 \\
\hline 2 & $26.45-30.89$ & 3 & 10 & $40.26-43.51$ & 3 & 10 \\
\hline 3 & $30.90-35.34$ & 5 & 16,7 & $43.52-46.77$ & 5 & 16,7 \\
\hline 4 & $35.35-39.79$ & 7 & 23,3 & $46.78-50.03$ & 10 & 33,3 \\
\hline 5 & $39.80-44.24$ & 4 & 13,3 & $50.04-53.29$ & 4 & 13,3 \\
\hline 6 & $44.25-48.69$ & 6 & 20 & $53.30-56.55$ & 3 & 10 \\
\hline
\end{tabular}

Tabel 3 Distribusi Frekuensi Data Hasil Smash

\begin{tabular}{lllllll}
\hline No & Kelas Interval & Test Awal & & Kelas Interval & \multicolumn{2}{c}{ Test Akhir } \\
& & $\mathrm{Fa}$ & $\mathrm{Fr}(\%)$ & & $\mathrm{Fa}$ & $\mathrm{Fr}(\%)$ \\
\hline 1 & $11.00-12.88$ & 4 & 13,3 & $20.00-22.90$ & 5 & 16,7 \\
\hline 2 & $12.89-14.77$ & 2 & 6,7 & $22.91-25.81$ & 6 & 20 \\
\hline 3 & $14.78-16.66$ & 5 & 16,7 & $25.82-28.72$ & 4 & 13,3 \\
\hline 4 & $16.67-18.55$ & 3 & 10 & $28.73-31.63$ & 6 & 20 \\
\hline 5 & $18.56-20.44$ & 7 & 23,3 & $31.64-34.54$ & 6 & 20 \\
\hline 6 & $20.45-22.33$ & 9 & 30 & $34.55-37.45$ & 3 & 10 \\
\hline
\end{tabular}

Berdasarkan table 1,2 dan 3 dapat diketahui data test awal (Pre Test) berbeda setelah diberikan perlakuan latihan selama 14 kali pertemuan.

\section{PEMBAHASAN}

Uji statistik yang digunakan adalah t-tes yaitu melihat pengaruh dalam satu kelompok yang sama pada taraf signifikan 0,05. Hasil test awal (pre test) peningkatan hasil servis, dengan jumlah sampel 30 diperoleh nilai tertinggi 26, skor terendah 15, rata-rata (mean) 21,66, dan standard deviasi (SD) 2,59. Selanjutnya dari analisis test akhir (post test) maka didapat skor tertinggi 39 skor 
terendah 26, rata-rata 31,27, dan standar deviasi $\_$(SD) 3,36. Adapun hasil pengujian hipotesis disajikan dalam tabel 4:

Tabel 4. Rangkuman Hasil Pengujian Hipotesis

\begin{tabular}{lccccccc}
\hline Hasil Servis Pemain & Mean & SD & thitun & ttabel & Hasil uji & Ket & \\
\cline { 1 - 3 } pre test (tes Awal) & 20,15 & 2,59 & 19,55 & 0,05 & 1,6991 & Signifikan & Ha ditolak \\
Post Test (Tes Akhir) & 30,13 & 3,36 & & & & & Ha diterima \\
\hline
\end{tabular}

Berdasarkan tabel untuk hasil servis dapat dilihat bahwa $t_{\text {hitung }}(19,55)$

$>t_{\text {tabel }}(1,6991)$. Hal ini berarti bahwa hipotesis penelitian dapat diterima. Dengan demikian dapat disimpulkan bahwa terdapat peningkatan keterampilan servis permainan bolavoli. Peningkatan hasil servis ini dapat dilihat dari skor rata-rata pemain adalah 20,15 pada tes awal menjadi 30,13 pada tes akhir.

Uji statistik yang digunakan adalah t-test yaitu melihat pengaruh dalam satu kelompok yang sama pada taraf signifikan 0,05 . Hasil test awal (pre test) peningkatan hasil servis, dengan jumlah sampel 30 diperoleh nilai tertinggi 48 , skor terendah 22, ratarata (mean) 35,57, dan standard deviasi (SD) 7,36. Selanjutnya dari analisis test akhir (post test) maka didapat skor tertinggi 56 skor terendah 37, rata-rata 46,5, dan standard deviasi (SD) 4,85. Adapun hasil pengujian hipotesis disajikan dalam table 5:

Tabel 5. Rangkuman Hasil Pengujian Hipotesis

\begin{tabular}{lcccccl}
\hline Hasil Servis Pemain & Mean & SD & thitung & ttabel & Hasil uji & Ket \\
\hline pre test (tes Awal) & 34,32 & 7,36 & 7,814 & 0,05 & 1,6991 Signifikan & Ha ditolak \\
Post Test (Tes Akhir) & 45,30 & 4,84 & & & & \\
\hline
\end{tabular}

Berdasarkan tabel untuk hasil passing dapat dilihat bahwa $t_{\text {hitung }}(7,814)>$

$t_{\text {tabel }}(1,6991)$. Hal ini berarti bahwa hipotesis penelitian dapat diterima. Dengan demikian dapat disimpulkan bahwa terdapat peningkatan keterampilan passing permainan bolavoli. Peningkatan hasil passing ini dapat dilihat dari skor rata-rata 
pemain adalah 34,32 pada tes awal menjadi 45,30 pada tes akhir. Pada penelitian dengan judul Peningkatan Hasil Belajar Passing Bawah Dalam Permainan Bola Voli Melalui Metode Self Check Dan Audio Visual Pada Murid Sdn 13 Arfai Manokwari juga mengalami peningkatan dalam pembelajaran (Darmawan and Rusli 2019)

Uji statistik yang digunakan adalah t-test yaitu melihat pengaruh dalam satu kelompok yang sama pada taraf signifikan 0,05. Hasil test awal (pre test) peningkatan hasil smash, dengan jumlah sampel 30 diperoleh nilai tertinggi 22, skor terendah 11, ratarata (mean) 17,93, dan standard deviasi (SD) 3,46. Selanjutnya dari analisis test akhir (post test) maka didapat skor tertinggi 37 skor terendah 20, rata-rata 28,6, dan standard deviasi (SD) 5,33. Adapun hasil pengujian hipotesis disajikan dalam table 6:

Tabel 6. Rangkuman Hasil Pengujian Hipotesis

\begin{tabular}{|c|c|c|c|c|c|c|c|}
\hline Hasil Servis Pemain & Mean & SD & & iitung tta & & Hasil uji & Ket \\
\hline pre test (tes Awal) & 16,80 & 3,46 & 9,042 & 0,05 & 1,69 & 1 Signifikan & Ha ditolak \\
\hline Post Test (Tes Akhir) & 27,50 & 5,33 & & & & & Ha diterima \\
\hline
\end{tabular}

Berdasarkan tabel untuk hasil servis dapat dilihat bahwa $t_{\text {hitung }}(9,042)$ $>t_{\text {tabel }}(1,6991)$. Hal ini berarti bahwa hipotesis penelitian dapat diterima. Dengan demikian dapat disimpulkan bahwa terdapat peningkatan keterampilan smash permainan bolavoli. Peningkatan hasil smash ini dapat dilihat dari skor rata-rata pemain adalah 16,80 pada tes awal menjadi 27,50 pada tes akhir.

Berdasarkan analisis data mengenai "Peningkatan Keterampilan bermain bolavoli mahasiswa melalui latihan gaya shelf check". Dari hasil analisis data 
bahwa keterampilan bermain bola voli melalui latihan gaya shelf chehk mengalami peningkatan, terbukti dengan hasil analisis data yang telah didapatkan berdasarkan nilai rata-rata dari tes awal dan tes akhir, seperti penelitian yang dilakukan dengan judul Perbedaan Pengaruh Metode Mengajar Reciprocal Dan Self Check Terhadap Peningkatan Keterampilan Teknik Dasar Bolavoli juga mengalami peningkatan yang siknifikan (Saptono and ROZZAQ 2013).

Hasil penelitian tersebut tidaklah didapatkan semata-mata dikarenakan kebetulan, melainkan para mahasiswa melakukan latihan pembelajaran dengan menggunakan latihan gaya self check dikarenakan dengan latihan gaya self check siswa dituntut tanggung jawab dalam menilai kemampuannya sendiri dalam melaksanakan latihan yang telah didesain oleh pelatih. Dengan demikian dapat dikemukakn dengan adanya latihan gaya self check ini terbukti bahwa peningkatan keterampilan permainan bolavoli dapat dilakukan dengan latihan gaya self check, dengan menggunakan latihan gaya self check ini akan meningkatkan kemampuan secara signifikan.

\section{KESIMPULAN}

Berdasarkan hasil penelitian dan pembahasan yang telah diuraikan, maka diambil kesimpulan sebagai berikut: (1) terdapat pengaruh yang signifikan metode mengajar self check terhadap peningkatan penguasaan keterampilan teknik dasar permainan servis bola voli; (2) terdapat pengaruh yang signifikan metode mengajar self check terhadap peningkatan penguasaan keterampilan teknik dasar permainan pasing bola voli; (3) terdapat pengaruh yang signifikan metode mengajar self check terhadap peningkatan penguasaan keterampilan teknik dasar permainan smash bola voli. 


\section{DAFTAR PUSTAKA}

Adang Suherman. 2000. Dasar-Dasar Penjaskes. Jakarta: Depdiknas.

Bompa, Tudor O. and G. Gregory Haff. 2000. Periodezation, Theory and Methodology of Training. BE.USA: Human Kinetics.

Darmawan, Syamsul, and Muhammad Rusli. 2019. "Peningkatan Hasil Belajar Passing Bawah Dalam Permainan Bola Voli Melalui Metode Self Check Dan Audio Visual Pada Murid Sdn 13 Arfai Manokwari." SPORTIVE: Journal Of Physical Education, Sport and Recreation 3(1): 1.

Depdiknas. 1999. Petunjuk Tes Keterampilan Bermain Bola Voli. Jakarta: Pusat Kesegaran Jasmani dan Rekreasi Departemen Pendidikan Nasional.

Giriwijoyo, S dan Sidik, D.Z. 2005. Ilmu Kesehatan Olahraga. Bandung: Remaja Rosdakarya.

Ma'mun, Among dan Toto Subroto. 2001. Pendekatan KeterampilanTestisDalam Pembelajaran Bola Voli Konsep Dan Metode Belajar. Jakarta: Depdiknas Terbuka.

Marta Dinata. 2004. Belajar Bola Voli. Jakarta: Cerdas Jaya.

Mosston, Muska. 2008. Teaching Phsycal Education. Columbus, Ohio: Company.

Pangrazi, Robet P. 2004. Dynamic Education For Elementry School Childern. Francisco: Benjamin Cummings.

Samsudi. 2005. Desain Penelitian Pendidikan. Semarang: Unnes Pres.

Saptono, Tri, and ABDUL ROZZAQ. 2013. "Perbedaan Pengaruh Metode Mengajar Reciprocal Dan Self Check Terhadap Peningkatan Keterampilan Teknik Dasar Bolavoli." Jurnal Pendidikan Jasmani Indonesia 7(2): 111-16. https://journal.uny.ac.id/index.php/jpji/article/view/3013.

Suharsimi, Arikunto. 2006. Jakarta: Rineka Cipta Prosedur Penelitian Suatu Pendekatan Praktik. Jakarta: Rineka Cipta.

Sukirno dan Waluyo. 2012. Cabang Olahraga Bola Voli Panduan Praktis Bagi Pelatih Profesional Menciptakan Atlet Untuk Meraih Prestasi Tinggi. Palembang: Unsri Press.

Thomas. J.R. dkk. 2015. Research Methods in Physical Activity-7th Edition. Illinois: HumanKinetics.

Viera. 2004. Bola Voli Tingkat Pemula. Jakarta: PT Radjagrafindo Persada. 